\author{
Nadirova G.E. \\ Doctor of Philology Sciences, professor, \\ al-Farabi Kazakh National University, Kazakhstan, Almaty, \\ e-mail: gulnad@mail.ru
}

\title{
NEW INTERNATIONAL INITIATIVES IN ACADEMIC PUBLISHING
}

The article is an extended review and analysis of the main trends in the field of processes of academic publications, the latest phenomena and initiatives that have appeared in the field of science and publishing abroad and are of significant interest also for Kazakhstani scientists. The initiatives of European scientific foundations and organizations have a great positive charge and are aimed at solving a number of extremely urgent and humane tasks to open up access to scientific knowledge to a wide range of scientists, entrepreneurs, practitioners and other people. Science should not be elitist, closed, and the results of scientific research carried out on the money of taxpayers cannot be sold to them for the reason that they were published in hard-to-reach rating journals. However, not everyone and not everywhere is ready to accept these changes positively. There are a number of reasons for this.

The author also considers other problems related to the review system, financing, selection criteria, as well as the problems of academic journals in Kazakhstan, which seek to raise their status to the international level.

Key words: academic publishing, indexed journals, open access, peer-review.

$$
\begin{gathered}
\text { Надирова Г.Е. } \\
\text { филология ғылымдарының докторы, профессор, } \\
\text { әл-Фараби атындағы Қазақ, ұлттық, университеті, Қазақстан, Алматы қ., } \\
\text { e-mail: gulnad@mail.ru }
\end{gathered}
$$

\section{Академиямық басқарудағы жаңа хамықаралық бастамалар}

Мақала академиялық жарияланымдар процесінің негізгі тенденцияларына, ғылым мен шетелде баспа ғылымында пайда болған соңғы құбылыстар мен бастамаларға кеңейтілген шолу және талдау болып табылады, сонымен қатар қазақстандық ғалымдар үшін үлкен қызығушылық, тудырады. Еуропалық ғылыми қорлар мен ұйымдардың бастамалары үлкен оң нәтижеге ие және ғалымдар, кәсіпкерлер, практиктер, сонымен қатар, басқа да тұтынушылар үшін ғылыми білімге қолжетімділікті қамтамасыз етуге, бірқатар шұғы^ және аАамгершілік мәселелерді шешуге бағытталған. Ғылым элитарлық, жабық болмауы тиіс, салық, төлеушілердің қаржысына орындалған жоғары рейтингтік журналдарға жариялаған ғылыми зерттеулердің нәтижелері оларға қайта сатылмауы қажет. Алайда, барлық адамдар және барлық жерде бұл өзгерістерді оң қабы^дауға дайын емес. Бұған бірқатар себептер бар.

Автор рецензиялау, қаржыландыру жүйесімен байланысты басқа да мәселелерді, іріктеу критерийлерін, сондай-ақ халықаралық деңгейге дейін өз мәртебесін көтеруге ұмтылатын Қазақстанның академиялық журналдарының мәселелерін қарастырады.

Түйін сөздер: академиялық баспа, индекстелген журналдар, ашық қол жетімділік, рецензия.

$$
\begin{gathered}
\text { НаАирова Г.Е. } \\
\text { Аоктор филологических наук, профессор, } \\
\text { Казахский национальный университет им. аль-Фараби, Казахстан, г. Алматы, } \\
\text { е-таil: gulnad@mail.ru } \\
\text { Новые международные инициативы в академическом } \\
\text { издательском деле }
\end{gathered}
$$

Статья представляет собой расширенный обзор и ана^из основных тенденций в области процессов акаАемических публикаций, последних явлений и инициатив, появившихся в сфере 
науки и издательского дела за рубежом и представляющих значительный интерес также Аля казахстанских ученых. Инициативы европейских научных фондов и организаций имеют большой позитивный заряд и направлены на решение ряда крайне актуальных и гуманных задач по открытию Аоступа к научным знаниям широкому кругу ученых, преАпринимателей, практических работников и прочих потребителей. Наука не Аолжна быть элитарной, закрытой и результаты научных исследований, выполненные на деньги налогоплательщиков, не могут продаваться им же по той причине, что они были опубликованы в труднодоступных рейтинговых журналах. ОАнако не все и не всегАа готовы принять эти изменения позитивно. Аля этого есть ряд причин.

Автор рассматривает и Аругие проблемы, связанные с системой рецензирования, финансирования, критериев отбора, а также проблемы академических журналов Казахстана, которые стремятся поднять свой статус до международного уровня.

Кмючевые слова: академическое издательство, индексируемые журналы, открытый доступ, рецензирование.

\section{Introduction}

The two main trends dominate today in the academic publishing world - the abandonment of the paper format of scientific journals in favor of electronic versions and the abandonment of paid subscription periodicals in favor of open access journals. While scientists in Kazakhstan, especially young researchers, and doctoral students, are concerned about the problems of publishing articles in foreign journals with a high impact factor, their colleagues in Europe are immersed in problems of, so to speak, the opposite nature.

The fact is that the European scientific community is actively discussing the so-called "Plan S", which was developed by Science Europe, an association of European research funding organizations (RFO) and research organizations (RPO), with the participation of the Center for European Political Strategy of the European Commission and a group of managers of national research funders. This plan proposes to publish the scientific products of young scientists, obtained as a result of government funding of their research only in open access journals and platforms. The plan, supported by the Bill and Melinda Gates Foundation, will be implemented from January 1,2020 , in $15 \mathrm{EU}$ countries and should eliminate financial problems in paying for publications of young researchers.

The initiators of the project also believe that it is time to change the approach to the evaluation of scientific research and authors, deeply rooted in many conservative structures, when hiring young $\mathrm{PhDs}$ focuses on where their articles were published and not on the real value of their publications. Moreover, science should be open and unrestricted, they believe, more daring in their findings and assumptions than allowed by strict, unwilling to risk editors and reviewers of reputable subscription journals. Moreover, to whom, they say, if not the advanced European science to begin this fruitful new movement?

The project initiators appealed to the relevant academic institutions of the United States and Asian countries with a request to support this initiative. To be fair, it should be noted that for some of these countries, the problem of tight binding of a scientist's success to publication in journals from the SCOPUS or Clarivate Analytics (Thomson-Reuters) database has never been relevant.

\section{Main part}

However, not all European scientists positively evaluate the Plan S. Many young people are frightened, on the one hand, by the lack of academic freedom in choosing a journal for publication and, on the other hand, by the risk of losing their job in those countries or universities for which publications in traditional indexed journals are a prerequisite for career advancement. Participation in international projects with obligatory publication in special journals may also be problematic for scientists. Some researchers even intend to move to another country, not affiliated in terms of Plan S. Some groups of scientists are concerned about privacy and security interests, as well as intellectual property rights and the economic competitiveness of the EU, and suggest taking a more balanced and selective approach to provide access to research data.

The situation with the publication of books looks even more dramatic. Publishers often charge authors, so-called production fees, even for a fully peer-reviewed, conscientious academic publication. Catherine M. Rudy, a professor of art history at the University of St. Andrews, reports that the editor of the Canadian university press requested a production fee of CAD 48,000 before he sends it to reviewers. Brill Publisher received 8,750 euros for the production of her book in 2017, which a private donor kindly paid 
for her. Open Book Publisher is asking for $£ 3,500$ for each published title. Because of all these costs, the more the author publishes, the poorer he becomes. If universities really want and are encouraged to advance research in the humanities, they need to align funding with costs [Rudi, K. 2019].

In January 2019, one of the most prestigious international journals "Proceedings of the National Academy of Sciences of the United States of America" (PNAS) announced the termination of its existence in the print form and the transition to the electronic format [Pells, 2019a]. The editorial board explains this step by the fact that sales of printed academic publications have sharply declined in the context of the rapid development of digital technologies, and the limitation of circulation leads to their appreciation. Considering that the number of articles published annually in this journal exceeds three thousand, a reduction in printing costs will obviously lead to a more flexible publishing policy in terms of the size of articles that were previously strictly limited and, as the academic community hopes, a reduction in the cost of their publication for authors.

The financial aspects of publishing high-ranking journals are extremely sensitive not only for authors but also for university libraries around the world. Thus, according to the latest data, a subscription to academic journals costs the leading universities in the UK an average of almost $£ 4$ million per year, and in other countries of the world, from $\$ 350,000$ to $\$ 9$ million, depending on the institution. It turns out that most of these costs are usually allocated to five major academic publishers - Reed-Elsevier, Springer, Wiley-Blackwell, Taylor \& Francis and SAGE [Pinfield, 2016]. It is particularly noticeable how significantly fees have increased over the past four years, up to $19 \%$. In this case, a strange situation arises. Researchers write articles, paying for their publication, and provide free peer-reviewing and expert reviews to publishing corporations that receive significant profits. Then, after publication, these corporations charge for products of academic research from researchers themselves. Besides researchers, there are other readers and organizations, taxpayers and sponsors, on whose money research was carried out. And they have to pay for access to information. According to the annual report of the RELX Group, Elsevier's revenue for 2016 was $£ 2.32$ billion [Macdonald and Eva, 2018].

However, the problem here is not only financial, but also ethical. It is precisely on its solution that the initiative we mentioned above - "Plan S", the European Open Access Initiative - is aimed at. The European Commission and three charitable foundations actually forbid researchers working with government money from publishing their results in top-rated publications, including Nature and Science, which are not yet accessible. In addition, publishing in hybrid open access magazines will also be banned, although a transitional phase will be undertaken. However, Plan S has now come up against sharp criticism of publishing corporations, as opponents claim that it will destroy the scientific publishing industry, undermine academic freedom, limit the capabilities of young researchers and disorientate academic communities [Pells, 2019b].

In addition, here we turn to the second trend, which is gradually growing in the global academic space. Open access journals have been around for about a decade, and the scale of these publications makes it possible to call them mega-journals, the most famous of which today is considered to be PLOS One with 31,509 articles published in 2013, a record year for it. Unlike most other journals specializing in certain sciences, it accepts articles in many scientific fields that are Life, STEM, and even social sciences. Today there are other mega-journals that publish approximately 2,000 articles per month, and this list includes Scientific Reports, BMC, BMJ Open, AIP Advances, SpringerPlus, PeerJ, SAGE Open, F1000 Research, FEBS Open Bio. Revenues of journals consist of article processing charges for publication (APC), and, under these conditions, the more articles are accepted, the higher the income of the journal is, so the rejection rate is quite low $30-35 \%$. The only selection criterion is the scientific validity of the article, and the review is made in a light format [Pells, 2018].

Leading traditional subscription journals pride themselves on rejecting most of the articles they receive. However, we all remember how grotesque the criteria of methodological complexity and high analytical ability turned out in the situation with the publication of the fake articles by James Lindsay, Helen Plakrouz and Peter Bogossian [Kennedy, 2018]. In fact, this fake project debunked the formality of the peer-review system that indexed journals are so proud of and generally called into question this system in its modern version.

However, papers of mega-journals are available for community-based open peer review involving online annotation, discussion, and rating. And, by the way, they receive the impact factor, which in 2017 was, for example, 2.766 at PLOS One, and 2.413 at the BMJ Open [BMJ Open, 2017].

It should be noted that progress in the open access movement has not been developing rapidly 
since its inception, although the number of such journals increased from 4,800 in 2009 to 9,500 in 2017 , and now about $30 \%$ of all published scientific works are available free of charge through open access platforms [Pells, 2019b].

Experts believe that the presence of high-yield mega-journals allows publishers to maintain their high-rating traditional journals, which, because of the small number of articles accepted for publication, do not cover all costs of the publication. In such a situation a relatively recently emerging model of publishing policy, "cascading peer-review", emerged, where manuscripts rejected by premium titles are transferred to moderate rejection-rate journals of the same publishing house, which, in turn, redirect rejected manuscripts down to a journal of the broadest scope possible, whose article processing fees are lower to encourage an author [Davis, 2010]. This situation mostly suits authors, and publishers reinforce their monopoly in this way, squeezing competing journals from the market.

Under these conditions, a number of university publishing houses are decisively moving to an openaccess platform, since, apart from the above-mentioned commercial and ethical aspects, this issue becomes a distinct social one. For example, University College London (UCL) is believed to be the first in the UK to launch an open access-publishing platform, as scientists are trying to move away from traditional scientific journals. The editorial board promises that the publication time will be reduced, published materials will be available to anyone with an Internet connection, and new review methods will make the assessment more transparent. UCL Press has already published about 50 open access research monographs that have been downloaded more than 650,000 times as of November 2017. Its transition to publishing articles was also preceded by the launch of open access platforms by several research sponsors, including Wellcome Open Research, launched in October 2016, and the Bill and Melinda Gates Foundation, which launched not just open, but free access on the Gates Open Research website in the fall of 2018. The foundation proceeds from the position that every person deserves the opportunity to lead a healthy and productive life, and one of the ways to achieve this goal is open access to high-quality research in the field of health care, education and economic development for society [Gates Open Research, 2018].

The New York Times article, published in 2015 after the Ebola pandemic in Liberia, Sierra Leone, and Guinea, in particular, confirms the need for open access. As it turned out, back in 1982, European scientists in the subscription journal Annals of Virology warned of a possible Ebola epidemic. If African health officials had read it in free access earlier, appropriate measures could have been taken, and the virus might not have killed at least 10,000 people. Open access would allow scientists in developing countries to become more involved in global scientific discourse, and governments of all countries to develop more effective solutions to social problems. Experts suggest that easier access to scientific discoveries for business and industry will also stimulate innovation and economic growth. Plan $\mathrm{S}$ is gradually joined by funding agencies in North America, Asia, and Australia, and research institutes in Germany and Sweden have terminated contracts with Elsevier.

It is quite natural that the largest academic publishers such as Springer have perceived this plan negatively. Springer Nature publishers claim that using their own professional editors and a high failure rate mean that article costs range from $€ 10,000$ to $€ 30,000$, and the availability of versions of open access articles elsewhere will jeopardize Springer Nature's ability to support these investments. Alternatively, they offer, firstly, that academics have a choice - to continue publishing in hybrid journals, which makes some articles freely available in exchange for a processing fee, and others for paid access, and, secondly, that very selective publications could go to this model. In addition, they want to use six-month embargo periods before articles in highly selective journals become free, and to keep subscription for peer-reviewed content.

In this situation, the review question gets a few different interpretation. Many scholars believe that if there is no evidence that the income of indexed journals is used to support academic activity, then they are more likely to refuse peer reviewing.

The event that took place last summer in the field of academic publishing deserves attention as the first, but perhaps not the last, occurrence of such kind in the international academic space. "The Review of Higher Education", which is one of the major high-impact journals included in the Clarivate Analytics database with Impact Factor 1.297 (2017) and 2.439 (Five-Year Impact Factor) suspended the receipt of manuscripts for consideration. The reason was, as indicated in the message on the journal website, "a large number of high-quality manuscripts received to date", in other words, the editorial board cannot cope with the flow coming from the authors of the articles, many of which have been submitted two years ago. It should be noted that "The Review of Higher Education" is one of the most prestigious journals in the field of higher education and the of- 
ficial journal of the Association for the Study of Higher Education.

The reasons for such an extraordinary phenomenon can be different - objective and subjective. First, the Review is published four times a year and each issue contains no more than five articles, which is less than $10 \%$ of applications. The journal has an online platform, but not open access. In addition to the limitation in the number of articles, the second reason may be a problem with the search for reviewers, perhaps the most acute for today, and, as it turned out, not only for this journal. The experience of the editors of other foreign scientific journals also shows that it is a very serious problem to find a qualified specialist in the required field, especially for interdisciplinary issues, who will agree to sacrifice his or her time completely free of charge. Especially if you consider that the reviewer should not only make a verdict - publish or not publish, but also give a professional and constructive review for the author. Peer review of journals is one of a series of collegiate activities for which academics do not receive remuneration, but which they do to maintain the academic ecosystem. For the most part, these academic teams are returning their share of revenue back to the academic ecosystem. For example, the Sociological Review Foundation uses it to fund activities for aspiring scientists, including a postdoctoral scholarship, as well as a wider investment in the sociological community. Other journals, however, channel a significant portion of their income into the pockets of their owners.

The growing volume of manuscripts, combined with the growing pressure of time for scholars, means that most of them must be abandoned if you want to do your own work. Finding the right balance is not easy. As one of the University of Auckland's professors said, "The academic review process is both a blessing and a curse. Reviewing can be a noble and generous act when you share your wisdom and experience usually without compensation - with fellow scientists you may, you do not even know. This includes constructive feedback, thereby supporting and enriching our own field of research. If everything is done well, this can contribute to the development of collegiality, encouraging fellow scientists and students create and publish their best work." Peer review: how to be a good referee [Ankeny et al., 2018]. Nevertheless, it is strange that the entire academic publishing industry rests on this volunteer service. Further challenges for peer review are related to speeding up the use of preprint servers. Preprints are published after a minimal check by the "affiliates" who check only the scientific nature of the article.
Whether journals in such a world will continue to conduct peer-reviewing before publication remains a question, if only because reviewers will have less incentive to participate. After all, if access to the manuscript can be obtained via the Internet immediately after submission, reviewers will no longer be able to get a preview of the latest research. Paying reviewers could compensate, but it would bring other problems, such as conflicts of interest. Instead, journals may decide to rely on peer review after users publish the archive. Sites such as PubPeer open the peer-review process to a much wider audience, crowdsourcing to evaluate an article. There is a special opportunity to combine peer-reviewing of this type after publication with publication in the public domain, and it becomes obvious that academic scientific publication is developing in this direction Most preprint servers allow you to add comments and subsequent corrections. While it seems unlikely that many people will be motivated to provide a comprehensive overview, usually presented during today's pre-publication process, there is probably the hope that enough people will want to comment briefly on some aspects of the article that are particularly striking.

How will these trends affect academic activities of Kazakhstani scientists? Considering that Kazakhstan's science today is not a major player in the global academic community, that it is concerned about the long process of transformation and research, and also taking into account the relatively limited market for academic publishing services within the country, these trends are unlikely to be actively discussed in scientific circles. At the same time, the inevitable involvement in the world scientific space in the $21^{\text {st }}$ century and the growing requirements for research ratings still require adjusting the internal publishing policies of universities and research centers in accordance with the current situation. Digital publishing is simply the most effective and cost-effective way to spread ideas in the world. We need to fully legitimize the digital, online, peer-reviewed publication and make it the norm.

Editors of Kazakhstani scientific journals also face this problem. Even with a large editorial board, few of its members are willing to constantly read and analyze numerous manuscripts, preferring to devote this time to their own research. In addition, given the new requirements for domestic academic journals that orient them towards the gradual entry into foreign indexed databases, about $30 \%$ of articles accepted for publication should be written in English, which creates additional difficulties for reviewing. 


\section{Conclusion}

The specific problems of Kazakhstani journals, especially those affiliated with universities, include the need to publish articles of Master and Ph.D students who must publish in scientific journals in accordance with the requirements of their educational programs. University journals, in turn, are obliged to accept these articles, since they share responsibility with their university for the implementation of these educational programs. Perhaps, editors should take a tougher stance on this issue, since the abundance of student work significantly affects the overall level and quality of the journal. However, the problem of "oversaturation", as in the case of the Review, is hardly possible in Kazakhstan's academic space, which faces a reverse situation. Because of the constant pressure on scientists and the requirement to publish in high-ranking foreign periodicals, many young and talented researchers prefer not to publish their materials in domestic journals, but to "storm" journals from the top list.

In particular, it is necessary to expand open access to scientific journals for all interested individuals and organizations, to revise the strong commitment of official structures to high-rating journals and orientation to publications in indexed periodicals, and, finally, to pay for peer reviews of experts in domestic academic journals, which will increase their responsibility for the work performed and, accordingly, the quality of scientific articles published in Kazakhstani journals.

\section{References}

Ankeny,R., Foster,R., Blyth,C., Debecker, D., Moriarty, Ph., Bhambra, G., Woodgett, J. (2018). Peer review: how to be a good referee. Retrieved from https://www.timeshighereducation.com/features/peer-review-how-be-good-referee. Accessed on 12.09.2019 BMJ Open (2017). Retrieved from https://bmjopen.bmj.com/pages/about/. Accessed on 15.02.2019.

Davis, Phil (2010). Cascading Peer-Review - The Future of Open Access? Retrieved from https://scholarlykitchen.sspnet. org/2010/10/12/cascading-peer-review-future-of-open-access/. Accessed on 15.02.2019.

Flaherty, C. 2018. Don't Even Think of Publishing in This Journal. Retrieved from https://www.insidehighered.com/ news/2018/08/16/major-higher-education-research-journal-suspending-submissions-clear-out-two-year. Accessed on 13.09.2019

Gates Open Research (2018). Retrieved from https://gatesopenresearch.org/. Accessed on 15.02.2019.

Kennedy, Laura (2018). Hoax papers: The shoddy, absurd and unethical side of academia. Retrieved from https://www.irishtimes. com/life-and-style/people/hoax-papers-the-shoddy-absurd-and-unethical-side-of-academia-1.3655500. Accessed on 15.02.2019.

Macdonald, Adriane and Nicole Eva ( 2018). It's time to stand up to the academic publishing industry. Retrieved from https:// www.universityaffairs.ca/opinion/in-my-opinion/time-stand-academic-publishing-industry/. Accessed on 15.02.2019.

Pells, Rachael (2018). UCL to launch open-access megajournal. Retrieved from https://www.timeshighereducation.com/news/ ucl-launch-open-access-megajournal. Accessed on 15.02.2019.

Pells, Rachael (2019a). As PNAS calls time on print, will more journals follow suit? Retrieved from https://www.timeshighereducation.com/news/pnas-calls-time-print-will-more-journals-follow-suit. Accessed on 15.02.2019.

Pells, Rachael (2019b). Nature boss warns Plan S could put journal out of business. Retrieved from https://www.timeshighereducation.com/news/nature-boss-warns-plan-s-could-put-journal-out-business. Accessed on 15.02.2019.

Pinfield, Stephen (2016). Mega-journals: the future, a stepping stone to it or a leap into the abyss? Retrieved from https://www. timeshighereducation.com/blog/mega-journals-future-stepping-stone-it-or-leap-abyss. Accessed on 15.02.2019.

Rudy, K. (2019). The true costs of research and publishing.

https://www.timeshighereducation.com/features/true-costs-research-and-publishing?utm_source=THE+Website+Users\&utm campaign=554746ced5-EMAIL_CAMPAIGN_2019_08_29_10_54\&utm_medium=emai1\&utm_term=0_daa7e51487554746ced5-61930941. Accessedon 29.08.2019. 